\title{
Pengembangan Metode Kuadran untuk Penentuan Kedalaman Benda Asing dengan Menggunakan Modalitas Komputer Radiografi
}

\author{
Emi Murniati $^{1)}$, Siti Masrochah ${ }^{1)}$, Ary Kurniawati ${ }^{1)}$ \\ ${ }^{1)}$ Jurusan Teknik Radiodiagnostik dan Radioterapi Poltekkes Kemenkes Semarang, Indonesia \\ e-mail : emimurniati@ymail.com
}

Received: Mei 31 ${ }^{\text {th }}$, 2019; Revised: July 01 ${ }^{\text {st }}, 2019$; Accepted: July $09^{\text {th }}, 2019$

\begin{abstract}
Background: With the use of CR radiology modalities, determining foreign objects is considered, which is then called the quadrant method. This study aims to explain the procedure and then the results are compared with the triangulation method which is a method of determining the depth of foreign objects previously used.

Methods: The type of research carried out is exploratory description research with an experimental approach. The radiograph was made in cases of foreign objects with 2 methods, namely the triangulation method and quadrant method using CR. Use phantom of femur, humerus, and thorax in which a foreign object is placed in it. The position of a foreign object is actually measured first and then the results of measuring the depth of a foreign object using the quadrant and triangulation method are compared with the results of the measurement of the actual foreign object.

Results: The results showed that the making of radiographs with quadrant methods as well as triangulation methods both used 2 exposures with an $\mathrm{x}$-ray so that the radiation exposure factor obtained by patients in both methods was not much different. Triangulation method has displayed measurement based on a formula that uses mathematical calculations by calculating the distance and magnification of objects. And quadrant method measurements are based on the data presented on the CR monitor screen without calculating the distance and magnification of the object.

Conclusion: Radiographic examination procedure determines the depth of foreign matter quadrant method using a Computer Radiography is carried out with two projections namely anteroposterior and lateral. While the difference in the depth of the foreign body quadrant method with the depth of the foreign body is actually found that the accuracy of the measurements carried out by the triangulation method is better than the measurements carried out by the quadrant method.
\end{abstract}

Keywords: Foreign Body; Computer Radiography; Quadrant Method

\section{Pendahuluan}

Dampak interaksi radiasi terhadap materi biologi yang dilalui meliputi efek somatic dan efek genetic. Efek somatic adalah terjadinya reaksi perubahan/kerusakan pada sel yang terkena langsung radiasi. Sedangkan efek genetic adalah terjadinya perubahan dan kerusakan sel akibat radiasi pada keturunan dari individu yang terkena radiasi langsung. Berdasarkan peluang (probabilitas) terjadinya efek negatif radiasi pada sel biologi dibedakan menjadi Efek stokastik dan efek non stokastik. Efek stokastik merupakan efek radiasi yang memiliki peluang seiring dengan paparan radiasi yang mengenai organ biologi. Efek stokastik ini memiliki peluang terjadi yang besar seiring dengan bertambahnya dosis radiasi yang mengenai organ biologi. Oleh karena itu efek stokastik ini tidak memiliki ambang dosis tertentu, akan tetapi efek ini merupakan efek tunda (lama) karena merupakan fungsi linier dari dosis radiasi yang terakumulasi. Efek ini tidak dapat dicegah akan tetapi harus dibatasi peluang terjadinya dengan menerapkan asas-asas proteksi radiasi yang baik. Sebagai contoh efek stokastik ini adalah kanker, leukemia dan lainnya. Sedangkan efek non stokastik disebut juga efek pasti karena tidak mengikuti fungsi probabilitas. Efek ini terjadi apabila telah terlampaui ambang dosis tertentu. Akan tetapi efek ini langsung terjadi begitu dosis ambang terlampaui. Sebagai contoh efek non stokastik ini adalah adanya kemandulan (sterilitas), luka bakar (eritema), katarak, kematian janin (teratogenetik) dan lain-lain. Karena efek ini pasti terjadi, maka efek non stokastik dapat dicegah dengan mengatur radiasi yang dimanfaatkan dibawah ambang dosis yang menimbulkan efek biologi (Travis, 2000).

Seiring dengan perkembangan teknologi bidang radiografi, untuk mendukung diagnosa penyakit, radiasi dimanfaatkan untuk salah satu penunjang 
medik yang penting dalam menentukan keberadaan benda asing dalam tubuh. Salah Satu kelainan yang sering ditemui di Rumah Sakit yang membutuhkan akurasi penegakan diagnosa dengan menggunakan radiasi pengion.

Keberadaan benda asing dalam tubuh umumnya dapat menganggu metabolisme tubuh, sehingga dapat mengancam jiwa seseorang. Oleh karena itu perlu dilakukan tindakan medis berupa pembedahan secepatnya dan tepat, agar jiwa pasien tertolong. Klinis Benda asing corpus alienum letaknya sangat bervariasi di seluruh tubuh tanpa kecuali, karena klinis ini merupakan kejadian trauma maupun kecelakaan kerja, sehingga diperlukan tindakan penegakan diagnosa yang akurat sehingga tidak terjadi resiko yang berbahaya bagi pasien.

Menurut Bontrager (2010), pemeriksaan adanya benda asing dalam tubuh dapat dilakukan dengan pemeriksaan dasar sesuai lokasi masuknya benda asing, dan teknik khusus penentuan benda asing dengan metode Paralak dan Triangulasi. Metode dasar penentuan kedalaman benda asing dilakukan dengan 2 proyeksi Antero posterior (AP) dan lateral dengan meletakkan marker di luka masuknya benda asing, akan tetapi dengan dua proyeksi yang terpisah ini tidak dapat secara akurat menentukan lokasi benda asing dalam organ, mengingat organ tubuh merupakan volume sehingga diperlukan teknik khusus yang dapat menentukan posisi sekaligus melakukan pengukuran jarak keberadaan benda asing terhadap permukaan tubuh.

Berdasarkan studi pendahuluan di beberapa instalasi Radiologi kegagalan pemeriksaan radiografi benda asing adalah tidak diperolehnya lokasi yang tepat termasuk jarak kedalaman benda asing, yang berdampak kesulitan saat tindakan operatif/pembedahan .Salah satu penyebab pengulangan adalah karena radiograf yang dihasilkan tidak dapat menggambarkan adanya lokasi yang tepat serta jarak benda asing dari permukaan tubuh.Oleh karena itu diperlukan inovasi khusus untuk penetuan benda asing. Sedangkan penolakan ini memberikan konsekuensi untuk melakukan pengulangan radiograf, yang memiliki resiko pula penambahan dosis radiasi pada pasien. Apabila ini terjadi, maka dosis yang diterima oleh pasien menjadi lebih besar, mengingat benda asing ini akan menjadi guiding (pemandu) saat tindakan pembedahan untuk mengeluarkan benda asing. Dengan demikian pengulangan ini sangat merugikan pasien khususnya menyangkut keselamatan pasien (patient safety) khususnya bidang radiasi.
Menurut Bontrager (2002), untuk menggambarkan benda asing dan penentuan kedalaman benda asing menggunakan paralaks perlu alat bantu khusus berupa lokalisir, akan tetapi sebagian besar Rumah Sakit tidak memiliki alat bantu tersebut, sehingga tidak dilakukan dalam mendukung tindakan medis selanjutnya. Sedangkan metode Triangulasi diperlukan teknik perhitungan matematis tertentu dengan 2 kali ekspose, Teknik ini memberikan konsekuensi jumlah radiasi yang cukup banyak dan perlu perhitungan yang rumit, sehingga tidak banyak pula digunakan di Rumah Sakit. Oleh karena itu diperlukan suatu metode khusus penentuan kedalaman benda asing dengan menggunakan modalitas Computer Radiografi (C-R).

Dengan terciptanya perkembangan teknologi pencitraan diagnostik, dewasa ini Komputer radiografi (C-R) merupakan suatu alat yang merupakan perpaduan pengolahan gambar radiografi (image procesing) dan sistem digitalisasi komputer yang memungkinkan dilakukan fungsifungsi logika maupun memoriyang baik untuk pengolahan citra. Dengan kelebihan tersebut, memungkinkan pendayagunaan $\mathrm{C}-\mathrm{R}$ ini untuk melakukan pengukuran jarak titik-titik tertentu secara otomatis yang tercover dalam display radiograf yang ditampilkan. Apalagi dengan kenyataan di lapangan hampir sebagian besar instalasi radiologi juga telah memanfaatkan C-R ini sebagai alat prosesing image yang telah menggantikan sistem pengolahan manual maupun otomatik. Oleh karena itu pemanfaatan modalitas $\mathrm{C}-\mathrm{R}$ ini dapat sangat mendukung bila didayagunakan dengan lebih luas tidak hanya pengolahan gambar, akan tetapi juga dapat digunakan sebagai alat bantu pengukuran yang tepat.

Dengan demikian diharapkan radiograf yang dihasilkan dapat berkualitas, tidak terjadi ketidaktajaman akibat posisi geometri (unshapnes geometri) dan gerakan (unsharpnes movement), sehingga presisi, akurasi yang tepat dan dosis radiasi yang diterima oleh pasien seminimal mungkin. Selain itu dengan metode ini dapat menunjang akurasi tindakan medis khususnya sebagai guiding tindakan operatif yang diperlukan dalam menunjang keselamatan pasien, karena fiksasi ini menghindarkan pasien terutama bila anak mempengaruhi pergerakan atau resiko jatuh dari meja pemeriksaan.

Penelitian ini akan mengkaji metode kuadran untuk penentuan kedalaman benda asing degan menggunakan komputer radiografi (C-R) untuk dapat menunjang tindakan medis pembedahan 
serta menunjang keselamatan radiasi dan keselamatan pasien. Dengan demikian diharapkan karya akademik ini dapat memberikan kontribusi bagi peningkatan pelayanan kesehatan di Rumah Sakit, khususnya pada pelayanan radiology dalam mewujudkan pelayanan prima dan berbasis pada keselamatan radiasi dan patient safety.

\section{Metode}

Jenis penelitian yang dilakukan adalah penelitian deskripsi eksploratif dengan pendekatan ekperimen. Dimana dilakukan pembuatan radiograf pada kasus benda asing dengan 2 metode yaitu metode triangulasi dan metode kuadran dengan menggunakan CR. Terlebih dahulu dilakukan pembuatan phantom organ femur, humerus dan thorax dimana diletakkan benda asing di dalamnya.
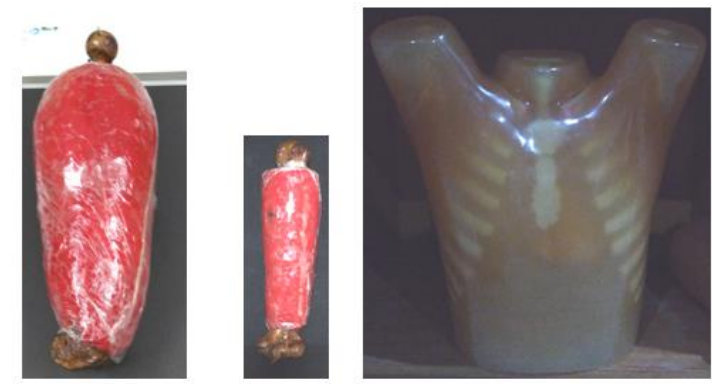

Gambar 1. Phantom organ femur, humerus, dan thorax

Tabel 1. Faktor eksposi dengan metode triangulasi dan metode kuadran

\begin{tabular}{cccccccc}
\hline \multirow{2}{*}{ Phantom } & \multicolumn{4}{c}{ Metode Triangulasi } & \multicolumn{3}{c}{ Metode Kuadran } \\
\cline { 2 - 7 } & $\mathrm{kV}$ & $\mathrm{mAs}$ & FFD & TSD & $\mathrm{kV}$ & $\mathrm{mAs}$ & FFD \\
\hline Femur & 50 & 3.2 & 80 & 10 & 60 & 8 & 100 \\
Humerus & 40 & 1.6 & 80 & 10 & 45 & 3.2 & 100 \\
Thorax & 60 & 5 & 90 & 15 & 70 & 10 & 100 \\
\hline
\end{tabular}

Posisi benda asing senyatanya diukur terlebih dahulu dan kemudian hasil pengukuran kedalaman benda asing dengan metode kuadran dan triangulasi dibandingkan dengan hasil pengukuran benda asing senyatanya tadi.

Populasi Penelitian ini adalah organ yang diperiksa dalam bentuk phantom, sedangkan sample pada penelitian ini adalah benda asing pada 3 organ yang terdiri dari: femur, humerus dan thoraks, pada semua organ dilakukan dengan 2 kali proyeksi pemotretan yaitu AP dan lateral dan pada setiap obyek dilakukan 3 kali pembuatan radiograf.

\section{Hasil dan Pembahasan}

Penelitian ini mengenai pengambangan metode kuadran untuk perhitungan kedalaman benda asing dengan menggunakan modalitas komputer radiografi (CR). Penelitian ini dilakukan di Laboratorium Jurusan Teknik Radiodiagnostik dan Radioterapi Politeknik Kesehatan Kemenkes Semarang pada Bulan Oktober 2018. Populasi pada penelitian ini adalah objek phantom, sedangkan sampel pada penelitian ini adalah benda asing pada 3 organ yang terdiri dari femur, humerus dan thorax.

\section{Deskripsi sampel}

Pada organ femur dan humerus peneliti membuat model phantom dengan tulang asli yang dibalut plastisin, sedangkan untuk phantom thorak peneliti menggunakan chest phantom N1 dengan merk Kyoto Kagaku. Phantom femur yang digunakan adalah femur kanan, sedangkan phantom humerus yang digunakan adalah humerus kiri. Benda asing diletakkan pada phantom sebagaimana tabel berikut.

\begin{tabular}{|c|c|c|c|c|c|c|}
\hline \multirow[b]{2}{*}{ Phantom } & \multicolumn{2}{|c|}{$\begin{array}{l}\text { Ukuran Phantom } \\
\qquad(\mathrm{cm})\end{array}$} & \multicolumn{4}{|c|}{$\begin{array}{l}\text { Ukuran Sebenarnya } \\
\text { Posisi benda asing dari } \\
\text { sisi }(\mathrm{cm})\end{array}$} \\
\hline & $\begin{array}{c}\text { Tebal } \\
\text { AP- } \\
\text { mAs }\end{array}$ & $\begin{array}{c}\text { Tebal } \\
\text { Lat } \\
\text { Kanan } \\
\text { (medial) } \\
\text {-Kiri } \\
\text { (lateral) }\end{array}$ & $\begin{array}{l}\text { Anter } \\
\text { ior }\end{array}$ & $\begin{array}{l}\text { Post } \\
\text { erior }\end{array}$ & $\begin{array}{c}\text { Lat } \\
\text { kana } \\
n \\
\text { (me } \\
\text { dial) }\end{array}$ & $\begin{array}{l}\text { Lat } \\
\text { kiri }\end{array}$ \\
\hline Femur & 11.50 & 12.00 & 1.80 & 8.90 & 6.50 & 5.30 \\
\hline Humerus & 7.30 & 7.50 & 1.90 & 5.10 & 5.50 & 1.20 \\
\hline Thorax & 22.00 & 30.50 & 11.00 & $\begin{array}{c}11.5 \\
0\end{array}$ & $\begin{array}{c}10.0 \\
0\end{array}$ & $\begin{array}{c}20.2 \\
0\end{array}$ \\
\hline
\end{tabular}

\section{Pembuatan radiograf}

Pembuatan radiograf dilakukan dengan dua metode, yaitu metode triangulasi dan metode kuadran. Pesawat sinar-X yang digunakan adalah Luminos RF Classic Siemens. Pada metode triangulasi dilakukan dua kali ekposi pada satu radiograf dengan melakukan pergeseran tabung sinar-X. Metode triangulasi dilakukan dengan dua proyeksi, anteroposterior dan lateral. Pembuatan radiograf metode kuadran dilakukan dengan dua proyeksi anteroposterior dan lateral. Pada proyeksi anteroposterior obyek phantom diberi penanda dengan marker disisi samping kanan/kiri tubuh sejajar dengan benda asing dan sedangkan pada proyeksi lateral obyek phantom diberi penanda dengan marker disisi anterior dan posterior tubuh sejajar dengan benda asing.

Dari tabel faktor eksposi, dapat dijelaskan faktor teknik yang digunakan pada pembuatan radiograf. Faktor teknik yang digunakan pada 
metode triangulasi meliputi tegangan tabung $(\mathrm{kV})$, arus tabung dan waktu (mAs), Focus film distance (FFD) dan Tube Shift Distance (TSD). Faktor teknik yang digunakan pada metode kuadran meliputi tegangan tabung $(\mathrm{kV})$, arus tabung dan waktu (mAs), Focus film distance (FFD).

Setelah dilakukan eksposi, masukkan imaging plate pada image reader CR. Pada radiograf metode triangulasi tampak dua gambaran benda asing, kemudian dilakukan pengukuran jarak antara kedua gambaran benda asing (Gambar 5.4). Radiograf metode kuadran terdiri dari dua proyeksi, anteroposterior dan lateral. Pada radiograf anteroposterior tampak bayangan benda asing dan marker pada sisi samping kanan/kiri phantom, kemudian dilakukan pengukuran jarak dari marker dengan benda asing. Pada radiograf lateral tampak bayangan benda asing dan marker pada sisi anterior dan posterior phantom, kemudian dilakukan pengukuran jarak dari marker dengan benda asing. Pembuatan radiograf pada masingmasing metode dilakukan sebanyak 3 kali.

\section{Hasil pengukuran}

Pada hasil radiograf metode triangulasi, dilakukan pengukuran jarak pergeseran benda asing pada radiograf (image shift distance). Kemudian dilakukan penghitungan jarak antara benda asing terhadap film (rumus *1) dan penghitungan jarak benda asing dari permukaan tubuh dengan menggunakan rumus $* 2$.

Pada hasil radiograf metode kuadran, dilakukan pengukuran dengan menggunakan tools pengukuran pada CR dari keempat posisi marker terhadap benda asing, yaitu sisi anterior, posterior serta samping kanan kiri tubuh/ sisi medial dan lateral.

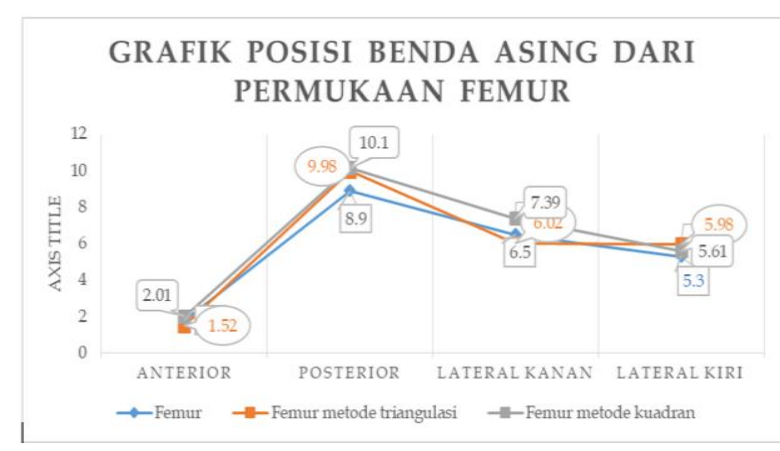

Gambar 2. Grafik posisi benda asing dari permukaan femur

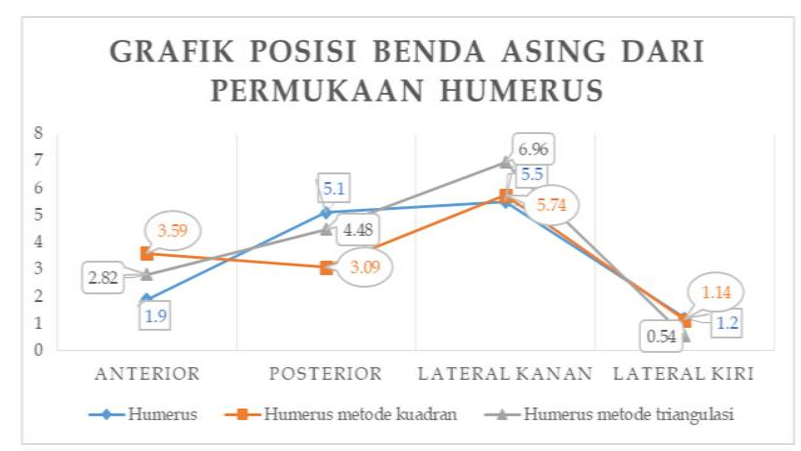

Gambar 3. Grafik posisi benda asing dari permukaan humerus

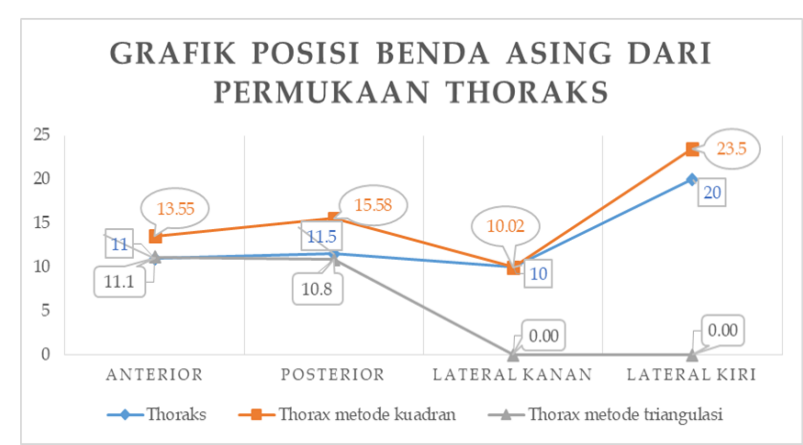

Gambar 4. Grafik posisi benda asing dari permukaan thorax

Tabel 3. Hasil pengukuran pada obyek femur metode triangulasi AP, lateral, dan metode kuadran

\begin{tabular}{|c|c|c|c|c|c|c|c|c|c|c|}
\hline \multirow[t]{2}{*}{ Phantom } & \multicolumn{3}{|c|}{ Metode Triangulasi AP } & \multicolumn{3}{|c|}{ Metode Triangulasi Lateral } & \multicolumn{4}{|c|}{ Metode Kuadran } \\
\hline & ISD & $\begin{array}{c}\mathrm{d}(\mathrm{BA}- \\
\text { posterior) }\end{array}$ & $\begin{array}{c}\mathrm{X}(\mathrm{BA}- \\
\text { anterior) }\end{array}$ & ISD & $\begin{array}{l}\text { d(BA- } \\
\text { lateral) }\end{array}$ & $\begin{array}{l}\mathrm{X}(\mathrm{BA}- \\
\text { medial })\end{array}$ & $\begin{array}{l}\text { BA- } \\
\text { Anterio }\end{array}$ & $\begin{array}{c}\text { BA- } \\
\text { Posterior }\end{array}$ & $\begin{array}{c}\text { BA- } \\
\text { Lateral } \\
\text { kanan } \\
\text { (lateral) }\end{array}$ & $\begin{array}{c}\text { BA- } \\
\text { Lateral } \\
\text { kiri } \\
\text { (meddi } \\
\text { al) }\end{array}$ \\
\hline Femur 1 & 1,38 & 9,70 & 1,80 & 0,79 & 5,86 & 6,14 & 1,83 & 10,14 & 7,64 & 5,41 \\
\hline Femur 2 & 1,44 & 10,06 & 1,44 & 0,82 & 6,06 & 5,94 & 2,00 & 10,10 & 7,20 & 5,70 \\
\hline Femur 3 & 1,46 & 10,19 & 1,31 & 0,83 & 6,13 & 5,87 & 2,00 & 10,21 & 7,32 & 5,73 \\
\hline Rata-rata & 1,43 & 9,98 & 1,52 & 0,81 & 6,02 & 5,98 & 2,01 & 10,15 & 7,39 & 5,61 \\
\hline SD & 0,04 & 0,25 & 0,25 & 0,02 & 0,14 & 0,14 & 0,19 & 0,06 & 0,3 & 0,18 \\
\hline
\end{tabular}


Tabel 4. Hasil pengukuran pada obyek humerus metode triangulasi AP, lateral, dan metode kuadran

\begin{tabular}{ccccccccccc}
\hline Phantom & \multicolumn{3}{c}{ Metode Triangulasi AP } & \multicolumn{3}{c}{ Metode Triangulasi Lateral } & \multicolumn{3}{c}{ Metode Kuadran } \\
\cline { 2 - 11 } & ISD & $\begin{array}{c}\mathrm{d}(\mathrm{BA}- \\
\text { posterior) }\end{array}$ & $\begin{array}{c}\mathrm{X} \text { (BA- } \\
\text { anterior) }\end{array}$ & ISD & $\begin{array}{c}\mathrm{d}(\mathrm{BA}- \\
\text { lateral) }\end{array}$ & $\begin{array}{c}\mathrm{X} \text { (BA- } \\
\text { medial) }\end{array}$ & $\begin{array}{c}\text { BA- } \\
\text { Anterio }\end{array}$ & $\begin{array}{c}\text { BA- } \\
\text { Posterior }\end{array}$ & $\begin{array}{c}\text { BA- } \\
\text { Lateral } \\
\text { kanan } \\
\text { (lateral) }\end{array}$ & $\begin{array}{c}\text { BA- } \\
\text { Lateral } \\
\text { kiri } \\
\text { (meddi } \\
\text { al) }\end{array}$ \\
\hline Humerus & 0.57 & 2,99 & 4,31 & 1,00 & 7,27 & 0,23 & 3,24 & 3,37 & 1,19 & 5,78 \\
Humerus & 0,62 & 2,70 & 3,60 & 0,98 & 7,14 & 0,36 & 3,84 & 2,93 & 1,14 & 5,74 \\
Humerus & 0,60 & 2,77 & 4,53 & 0,88 & 6,47 & 1,03 & 3,70 & 2,97 & 1,10 & 5,70 \\
Rata-rata & 0,60 & 2,82 & 4,48 & 0,95 & 6,96 & 0,54 & 3,59 & 3,09 & 1,14 & 5,74 \\
SD & 0,03 & 0,15 & 0,15 & 0,06 & 0,43 & 0,43 & 0,31 & 0,24 & 0,05 & 0,04 \\
\hline
\end{tabular}

Tabel 5. Hasil pengukuran pada obyek thorax metode triangulasi dan kuadran

\begin{tabular}{cccccccc} 
& \multicolumn{3}{c}{ Metode Triangulasi } & \multicolumn{5}{c}{ Metode Kuadran } \\
\cline { 2 - 8 } Phantom & ISD & $\mathrm{d}$ & $\mathrm{X}$ & Anterior & Posterior & $\begin{array}{c}\text { Lateral } \\
\text { Kanan }\end{array}$ & $\begin{array}{c}\text { Lateral } \\
\text { Kiri }\end{array}$ \\
\hline Thorax & 2,40 & 12,40 & 9,60 & 13,81 & 15,51 & 9,98 & 23,45 \\
Thorax & 2,50 & 10,06 & 11,94 & 12,88 & 15,52 & 9,84 & 23,37 \\
Thorax & 2,45 & 10,19 & 11,81 & 13,96 & 15,72 & 10,25 & 23,69 \\
Rata-rata & 2,45 & 10,88 & 10,88 & 13,55 & 15,58 & 10,02 & 23,50 \\
SD & 0,05 & 1,32 & 1,32 & 0,59 & 0,12 & 0,21 & 0,17 \\
\hline
\end{tabular}

Tabel selisih hasil pengukuran letak benda asing dari permukaan objek $(\mathrm{cm})$ terhadap ukuran sebenarnya

Tabel 6. Selisih hasil pengukuran letak benda asing dari permukaan objek antara metode triangulasi dan metode kaudran

\begin{tabular}{|c|c|c|c|c|c|c|c|c|}
\hline \multirow[b]{2}{*}{$\begin{array}{c}\text { Phant } \\
\text { om }\end{array}$} & \multicolumn{4}{|c|}{ Metode Triangulasi } & \multicolumn{4}{|c|}{ Metode Kuadran } \\
\hline & $\begin{array}{l}\text { Ante } \\
\text { rior }\end{array}$ & $\begin{array}{l}\text { Post } \\
\text { erior }\end{array}$ & $\begin{array}{c}\mathrm{La} \\
\mathrm{t} \\
\mathrm{ka}\end{array}$ & $\begin{array}{l}\text { Lat } \\
\mathrm{ki}\end{array}$ & $\begin{array}{c}\text { Ant } \\
\text { erio } \\
\mathrm{r}\end{array}$ & $\begin{array}{l}\text { Post } \\
\text { erio } \\
r\end{array}$ & $\begin{array}{l}\text { Lat } \\
\text { ka }\end{array}$ & $\begin{array}{l}\mathrm{La} \\
\mathrm{ki}\end{array}$ \\
\hline Femur & 0,28 & 1,08 & $\begin{array}{l}0, \\
48\end{array}$ & $\begin{array}{c}0,6 \\
8\end{array}$ & $\begin{array}{c}0,2 \\
1\end{array}$ & $\begin{array}{c}1,2 \\
5\end{array}$ & $\begin{array}{c}0,8 \\
9\end{array}$ & 0,31 \\
\hline $\begin{array}{l}\text { Hume } \\
\text { rus }\end{array}$ & 0,92 & 0,62 & $\begin{array}{l}1, \\
46\end{array}$ & $\begin{array}{c}0,6 \\
6\end{array}$ & $\begin{array}{c}1,6 \\
9\end{array}$ & $\begin{array}{c}2,0 \\
1\end{array}$ & $\begin{array}{c}0,2 \\
4\end{array}$ & 0,06 \\
\hline $\begin{array}{c}\text { Thora } \\
x\end{array}$ & 0,92 & 0,62 & - & - & $\begin{array}{c}1,6 \\
9\end{array}$ & $\begin{array}{c}4,0 \\
8\end{array}$ & $\begin{array}{c}0,0 \\
2\end{array}$ & 0,35 \\
\hline
\end{tabular}

Prosedur pemeriksaan radiografi penentuan kedalamanan benda asing metode kuadran dengan menggunakan komputer Radiografi

Sekaitan dengan berkembangnya teknologi pencitraan di bidang radiografi, akhir-akhir ini penggunaan computed radiografi (CR) semakin berkembang dengan pesat. Hal ini disebabkan karena penggunaan $\mathrm{CR}$ ini dipandang sangat menguntungkan, mudah dalam pengoperasian dan bahkan dapat meminimalisir kerugian secara finansial dengan mengurangi angka reject film.

Pada penatalaksanaan radiograf untuk menginvestigasi benda asing secara teori telah ditemukan beberapa metode antara lain metode triangulasi dan paralaks. Dimana pada metode- metode tersebut dilakukan pengukuran secara matematis untuk mendapatkan posisi dari benda asing berdasarkan radiograf yang telah dibuat. Hal tersebut dirasakan kurang efektif dan efisien karena faktor waktu pembuatan radiograf dan waktu penghitungan jarak benda asing. Selain itu kesalahan juga bisa terjadi bila petugas tidak teliti atau kurang memiliki pengetahuan dalam penghitungan hasilnya. Untuk itulah kemudian dicari alternatif pengukuran jarak benda asing dengan menggunakan modalitas computed radiografi dimana pada terdapat tools untuk melakukan pengukuran jarak pada radiograf yang dihasilkan.

Metode kuadran adalah salah satu metode untuk membagi bagian organ tubuh menjadi 4 arah yaitu dari arah depan (anterior) - belakang (posterior) samping luar (eksternal) dan samping dalam (medial) yang digunakan untuk acuan pembedahan benda asing. Dan pada pengukuran benda asing dengan metode kuadran ini dilakukan prosedur sebagai berikut: radiograf metode kuadran terdiri dari dua proyeksi, anteroposterior dan lateral serta diberikan marker pada samping kanan-kiri dan anterior-posterior phantom. Pada radiograf anteroposterior tampak bayangan benda asing dan marker pada sisi samping kanan/kiri phantom, kemudian dilakukan pengukuran jarak dari marker dengan benda asing. Pada radiograf lateral tampak bayangan benda asing dan marker pada sisi anterior dan posterior phantom, kemudian dilakukan pengukuran jarak dari marker dengan benda asing. 
Perbedaan kedalaman benda asing metode kuadran dengan kedalaman benda asing senyatanya

Dari uraian yang telah dipaparkan pada bagian hasil penelitian terutama pada tabel $5.8 \mathrm{di}$ atas dapat diketahui bahwa akurasi pengukuran yang dilakukan dengan metode triangulasi lebih baik daripada pengukuran yang dilakukan dengan metode kuadran. Hal ini disebabkan triangulasi menggunakan penghitungan secara matematis dengan memperhitungkan jarak dan perbesaran obyek. Sedangkan kelemahan dari metode triangulasi adalah tidak dapat digunakan untuk memperkirakan arah masuknya benda asing tersebut ke dalam tubuh.

Metode kuadran mempunyai kelemahan tidak terlalu akurat dalam pengukuran benda asing, hal ini diakibatkan data yang tersaji pada layar monitor, dimana kemudian dilakukan pengukuran dengan tools yang ada pada CR, masih harus mempertimbangkan adanya perbesaran atau magnifikasi. Sedangkan kelebihan dari metode ini adalah dapat mengetahui secara lebih jelas posisi benda asing terhadap ke empat kuadran tubuh sehingga dapat terlihat benda asing tersebut lebih dekat bila diambil dari posisi kuadran yang mana.

\section{Simpulan}

Prosedur pemeriksaan radiografi penentuan kedalamanan benda asing metode kuadran dengan menggunakan komputer Radiografi. Radiograf metode kuadran terdiri dari dua proyeksi, anteroposterior dan lateral. Pada radiograf anteroposterior, diberikan marker pada samping kanan-kiri phantom sehingga tampak bayangan benda asing dan marker pada sisi samping kanan/kiri phantom, kemudian dilakukan pengukuran jarak dari marker dengan benda asing. Pada radiograf lateral, diberikan marker untuk menandai bagian anterior dan posterior, sehingga tampak bayangan benda asing dan marker pada sisi anterior dan posterior phantom, kemudian dilakukan pengukuran jarak dari marker dengan benda asing.

Perbedaan kedalaman benda asing metode kuadran dengan kedalaman benda asing senyatanya Akurasi pengukuran yang dilakukan dengan metode triangulasi lebih baik daripada pengukuran yang dilakukan dengan metode kuadran hal ini disebabkan pada metode triangulasi pengukuran dengan menggunakan rumus matematis yang sudah memperhitungkan jarak dan perbesaran obyek. Sedangkan pada metoda kuadran hasil pengukuran menggunakan tools pada
CR belum memperhitungkan faktor pembesaran gambar atau magnifikasi.

\section{Daftar Pustaka}

Aras, MH., et al. Comparison of the Sensitivity for Detecting Foreign Bodies Among Conventional Plain Radiography, Computed Tomography And Ultrasonography. The British Institute of Radiology. 2010.

Artawijaya,I Gusti Ngurah Agung. Proses terjadi sinarX..wordpress.com. 2008. diakses tanggal 10 Februari 2018. Jam 12.30 WIB.

Akhadi, Mukhlis. Dasar-Dasar Proteksi Radiasi. Jakarta: Rineka Cipta. 2000.

Bar.ray. Personal Radiation Protection. sh genx.gif. 2010. diakses tanggal 26 Maret 2018. Jam 11.00 .

Endranatha, Damianus, Desain Aplikasi Software Alat Bantu Pengukuran Kedalaman Benda Asing Berbasis Visual Basic 2010, Poltekkes Kemenkes Semarang, 2012

Jarraya, M., et al. Multimodality Imaging of Foreign Bodies of the Musculoskeletal System. American Journal of Roentgenology. 2014.

Momoniat, HT., dan England, A., An Investigation Into the Accuracy of Orbital X-rays, when Using $C R$, in Detecting Ferromagnetic Intraocular Foreign Bodies. Elsevier. 2017.

Pinto, A., et al. Radiological and Practical Aspects of Body Packing. The British Institute of Radiology. 2014

Sheridan, N., dan McNulty, JP.. Computed Radiography Versus Indirect Digital Radiography for the Detection of Glass Soft-tissue Foreign Bodies. Elsevier. 2016.

Yan, Z., Li T., dan Ling LQ.. Detection of Foreign Bodies and Bubble Defect in Tire Radiography Images Based on Total Variation and Edge Detection. IOPScience. 2013. 